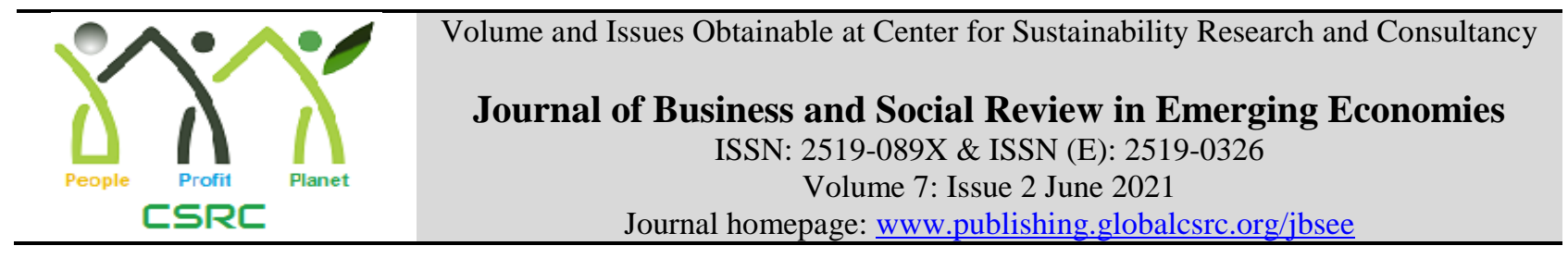

\title{
Intellectual Capital, Political Uncertainty and Firm Performance: Evidence from Pakistan
}

*Farheen Zahra Hussain, Bahauddin Zakariya University, Multan, Pakistan

Ayub Khan Mehar, Iqra University, Karachi, Pakistan

*Corresponding author's email: farheenzh@gmail.com

ARTICLE DETAILS

History

Revised format: Mar 2021

Available Online: Apr 2021

\section{Keywords}

Intellectual capital,

Financial Performance,

Political Uncertainty, VAIC,

IC Components

JEL Classification

M11,M12

\section{OPEN $\bigcirc$ ACCESS}

\section{ABSTRACT}

Purpose: This research has examined the impact of Intellectual Capital (IC) on performance of the firms in Pakistan while considering political uncertainty as moderating variable. Value Added Intellectual Coefficient (VAIC) model by Pulic (1998) has been used to calculate IC and its components and ROA is used to measure firm's performance. Design/Methodology/Approach: The research used secondary data of firms, related to manufacturing sectors, listed in Karachi Stock Exchange-KSE 100 Pakistan for a ten-year period of 2010-2019. Regression Model has been employed to investigate the hypothetical relationship between IC and firm performance. Findings: Results of this paper revealed that $\mathrm{CEE}$ and $\mathrm{CCE}$ have a significant positive relationship with the financial performance of firms in Pakistan whereas SCE has negative effect on the financial performance of the firms. Furthermore, the findings suggest political instability as a significant moderating variable on the relationship among intellectual capital, its components and firms' performance. Implications/Originality/Value: The findings suggest that the IC of Pakistani firms is driven by physical and customer capital which implies the need for efficient utilization of physical and relational resources primarily. This research is the first attempt in investigating the relative importance of intellectual capital success of any firm under political uncertainty.

(C) 2021 The authors, under a Creative Commons AttributionNonCommercial 4.0

Recommended citation: Hussain, F.Z., Mehar,A.K., (2021). Intellectual Capital, Political Uncertainty and Firm Performance: Evidence from Pakistan. Journal of Business and Social Review in Emerging Economies, 7 (2), 265-278

\section{Introduction}

The era of 19th century is known as the industrial age in which wealth creation was measured as the net increase in the production quantity. In 20th century, the age of knowledge-based economy emerged where wealth creation primarily depended on the ability of any organization for creating knowledge, skills, creativity, and processes known as Intellectual Capital (IC). Though it has long been ignored, the contribution of intellectual capital to a firm's performance is critical. The IC's presence is verified by the difference of market value and its book value. However, IC isn't 
appropriately recognized and recorded on the balance sheet of companies. It is argued that all the events that inclined to affect the firm's financial performance should be recorded in annual reports of the firms (Zambon, 2004).

As intellectual capital has been playing the role of the main contributor towards the value creation of firms (Su, 2014), knowledge-based, fast-changing, and technology-driven economies are replacing most of the economies in manufacturing sectors (Cañibano, Garcia-Ayuso, \& Sanchez, 2000).World Bank report (1998) also points out that knowledge-based resources make a greater contribution to people's living standards in developed countries than that of resourcebased inputs (Wambai, Madya, Derashid, \& Ibrahim, 2019).

This shift of economies from production-base to knowledge-base has generated significant growth both at national and global scale in the effective measurement and management of IC (M. Cabrita \& Vaz, 2005). Similarly, it is argued by Cahill and Myers (2000) that the shift towards knowledge-based economies has facilitated effective measurement and management of IC. Therefore, organizations today, are making significant investment in educating and training of their staff for building IC resources, which are fundamental for building a knowledge based economy (Foray, 2006). There are many studies (Lu, Wang, \& Kweh, 2014; Joshi et al., 2013; Kamal, Rahim, Husain, \& Ismail, 2012; Clarke et al., 2011; Young, Su, Fang, \& Fang, 2009; Gan \& Saleh, 2008; Chen, 2005) conducted at national and regional levels for the measurement of IC efficiency and positive relation of IC with firms' performance was found. Because of the role of IC in almost all industries, these studies have centered on a variety of industries ranging from banking to textiles.

Some studies have however, revealed a delayed relationship between the investments by firms and the resulting intellectual capital performance of the firms (Vaisanen, Kujansivu, \& L€onnqvist, 2007). Similarly, some other studies (Mosavi, Nekoueizadeh, \& Ghaedi, 2012; Maditinos, Chatzoudes, Tsairidis, \& Theriou, 2011; Rehman et al., 2011) have highlighted only one component of VAIC model i.e. HCE to have a relationship with the firm's performance. More or less studies on the other hand (Mehralian, Rajabzadeh, Sadeh, \& Rasekh, 2012; Ferraro \& Veltri, 2011; S,amiloglu, 2006) highlighted the non-existence of any relationship between IC and a firms' financial performance.

The author attempted an empirical analysis of the relationship between firm financial results and IC using the VAIC model in this research, focusing on the manufacturing firms of Pakistan during the period of 2010 to 2019. Regression analysis based on panel data used in the study, which included both cross sectional and time dimension analysis. As reported in the literature (Perotti \& Van Oijen, 2001; Diamonte, Liew, \& Stevens, 1996; Erb, Harvey, \& Viskanta, 1996), political uncertainty being the significant factor in the stock markets, therefore political risk has been used as the moderating factor. This is one of the first studies to consider political instability as a moderating factor in connection to IC and performance of firms. When political instability is used as a moderating variable, the findings show that VAIC has a statistically significant and positive impact on firm's financial results. On the component level of the VAIC, CEE and CCE have a positive impact on the firm's financial results, while SCE has a negative impact. Therefore, in order to achieve higher profitability, firms operating in the Pakistani manufacturing sector need to effectively and efficiently use their financial, physical and customer capitals.

The first part of the study describes IC and discusses the relationship between it and a company's financial results, while in the second part the concept of IC is explained and the relationship of IC and the financial performance of businesses is examined. The study's data, variables, methodology, and hypothesis are all explained in the third part. The study's analytical results have been analyzed in the fourth part, while in the final overall findings of the study are 
summarized.

\section{Literature Review Intellectual Capital}

Scholars have not yet reached to universally accepted definition of Intellectual Capital; instead, various scholars have interpreted it in different ways. However, the existence of IC is verified by the difference of market worth and its book worth, and has a positive effect on the financial performance of the company but is not appropriately recognized and recorded on the balance sheet of the company. (Mondal \& Ghosh, 2012; Kayacan \& Alkan, 2005; Brooking, 1996).

Not only the literature lacks the consensus on the definition of IC, but also the components of IC are not agreed upon among researchers, either. However, most of the studies on IC (Bontis, 2001a; Pulic, 1998, 2004; Subramaniam \& Youndt, 2005a; Sveiby, 1997) agree on the three key IC elements named as human, structural and relational capital.

Human capital in definition is the knowledge that an organization loses when its people leave, including knowledge, skills, talents, experience, and expertise of its departing employees. Structural capital refers to an organization's framework, structure, and procedures, as well as nonphysical elements like databases, organizational charts, strategies, policies, processes and procedures. Customer capital, on the other hand, applies to all intangible assets that govern and control an organization's relationships. It also includes the company's interactions and relations with stakeholders, like consumers, vendors, and shareholders, etc. (Kurt, 2008; Mondal \& Ghosh, 2012; Joshi et al., 2013).

Following the discovery that intellectual capital aids organizations in value creation and productivity improvement, various methods to measure intellectual capital were created. Prominent methods for measuring intellectual capital include EVA (Steward, 1991), MVA (Bontis, 1998), Balanced Scorecard (Kaplan \& Norton, 1996), Calculated Intangible Value (Steward, 1997), Intellectual Capital Services' IC-index (Roos et al., 1997), Skandia IC Navigator (Edvinsson, 1997), Tobin's Q (Luthy, 1998), the Technology Broker's IC Audit (Brooking, 1996), Intangible Asset Monitor (Sveiby, 1997), and Value Added Intellectual Coefficient (VAIC) Model (Pulic, 1998, 2004).

This study has applied the monetary-based model -VAIC (Pulic, 1998) to measure IC. VAIC is considered relatively an easy model to apply and an effective model for measuring intellectual capital performance of any firm for making comparisons between firms. The VAIC model shows an organization's analytical capacity as well as whether or not the organization is using its resources efficiently. Thus, as argued by Pulic (2004) the VAIC calculates the new value generated with the investment of monetary unit in each organizational value generation source. The higher VAIC, the more value is added by the organization's total sources.

\section{Financial Performance and VAIC}

The VAIC is commonly used to assess the output of firms' intellectual capital in a variety of countries and industries. VAIC model was extensively utilized by many studies (Sumedrea, 2013; Vishnu \& Gupta, 2014; Lu, Wang, \& Kweh, 2014; Berzkalne \& Zelgalve, 2014; Alhassan \& Asare, 2016; Hejazi, Ghanbari, \& Alipour, 2016; Meles, Porzio, Sampagnaro, \& Verdoliva, 2016b; Nadeem, Gan, \& Nguyen, 2018; Ozkan, Cakan, \& Kayacan, 2017; Bayraktaroglu, Calisir, $\&$ Baskak, 2019) because of its effectiveness and easy comprehension.

To explain the prevailing association of IC and firms' performance, existing studies give mixed results. Some studies (Bayraktaroglu et al., 2019; Cabrilo \& Dahms, 2018; Cisneros \& Hernandez-Perlines, 2018; Kianto, Sáenz, \& Aramburu, 2017; Nadeem, Gan, \& Nguyen, 2017; 
Oppong \& Pattanayak, 2019; Iqbal \& Zaib, 2017; Ayub et al., 2017; Shumaila \& Afza, 2014a) found significantly positive association of IC with performance of firms whereas some other studies (Aruppalal, Wickramasinghe, \& Mahakalanda, 2015a; Rahman \& Ahmed, 2012) found insignificant relationship.

Oppong \& Pattanayak (2019) very recently, measured employee productivity (EP) to examine how IC investment by banks improves the productivity by using panel data of 73 commercial banks for 12-year period between 2006-2017 in India and applied the panel data modelling for the analysis. Only CEE, among the three IC components, found to influence the EP of banks in India. However, overall a positive association was found between the components of IC and ATO. In addition, in a study of the Turkish manufacturing sector, Bayraktaroglu et al. (2019) explored the moderating role of IC components on the impact of physical capital on firm performance. Results showed the moderating impact of capital efficiency in innovation on the relationship between SCE and performance. Further, Cabrilo \& Dahms (2018) explored strategic knowledge management (SKM) for its moderation effect in 101 Serbian companies and found the direct effect of relational and structural capital on financial perform in innovation. Though the study found no direct significant effect of human capital on innovation performance, when moderated by SKM the relationship became significant. Furthermore, Cisneros \& HernandezPerlines (2018) studied the relation of various IC components and organizations' financial performance in SMEs in the Baja California region, Mexico. The results showed a positive influence of four IC components which is consistent with several Mexican and international studies. Additionally, information management was added as a moderating variable and the result was that the relationship between IC and operating profit (OP) was negatively moderated.

As far the literature on Pakistan is concerned so the impact of corporate governance and IC on banking sectors' financial performance was also studied by Iqbal \& Zaib (2017). The relationship of corporate governance, IC and financial performance of two groups of banks i.e., Commercial banks and Microfinance \& investment banks, were examined using Generalized Least Squared (GLS) model. In both groups of banks, they found a significant impact of corporate governance on IC. In microfinance and investment banks, HCE was found to be associated significantly with financial performance, whereas SCE was also found to be required for the good financial performance of commercial banks. In addition, in another study the impact of human capital (HC) and its various configurations on Innovative Capability (IC) of the banking sector of Pakistan were also investigated by Ayub et al. (2017). A positive relationship between IC and HC was found by the results. Further, Khalique et al. (2015) also assessed the relations between subcomponents of IC and organizational success in SMEs operating in Pakistan's electrical and electronics manufacturing sector. Data was collected from a sample of 247 respondents from Pakistani SMEs in Gujranwala and Gujarat, using standardized questionnaires. The research hypotheses were tested via multiple regression analysis. The findings showed the goodness of fit of intellectual capital's overall regression model except for human capital which appeared insignificant. Furthermore, Rehman et al. (2011) also used VAIC for measuring IC impact on the firms' performance and its efficiency for Modaraba companies listed on the KSE, Pakistan. The findings revealed that $\mathrm{HC}$ was the major contributor to value creation for modaraba companies. The financial performance of Islamic banks was found to be significantly associated with all of the components, including CEE, HCE, and SCE. In a similar study, Khalique et al. (2011) found a significantly positive association of IC components with the performance of the banking sector of Islamabad stock exchange of Pakistan. Similarly, the strong association of IC with the bank's financial performance in Pakistan was also revealed by the results found in the study of Khan et al. (2012). In addition, Bharathi (2010) also measured the banks' performance in Pakistan and applied VAIC for measuring IC efficiency for the years 2004-05 and 2005-06. The secondary data was used and multiple regression was applied for finding the best linear fit model. The study concluded, on IC efficiency levels, the performance of private sector banks was better than other 
banks' performance in Pakistan. The reason for the good performance was found to be efficient in the utilization and management of human capital.

Most of the above-mentioned studies found a positive relationship between intellectual capital and its components. However, a few studies did not find this relationship as significant. For example, Makki et al (2008) ranked the IC performance of the Lahore Stock Exchange index' listed companies (LSE-25), Pakistan by using VAIC. In findings, high performance was shown by chemical, cement, oil \& gas sectors. However, the performance of the banking sector was average; and the least was of the public sector. Likewise, Aruppalal et al. (2015b) investigated the IC impact on the Sri Lankan banks' performance. Researchers used VAIC to calculate and measure the IC while ROE and $\mathrm{M} / \mathrm{B}$ ratios used for measuring banks' performance. It is revealed that the efficiency of invested capital has a considerable contribution to financial performance. However, no strong positive relationship was found between HCE, SCE and financial performance. In addition, Khalique, Nassir Shaari, et al. (2011) examined the relationship of IC and performance in Pakistan's division of electrical gadgets and used Pearson's relationship and found that there is a significant and optimistic correlation between structural capital and client capital with performance. Whereas, human capital found to have little impact on the success of the firms.

Further, Pal and Soriya (2012) also analyzed IC's efficiency in the textile and pharmaceutical sectors of India in a cross-industry study. The study applied the VAIC model for the measurement of IC effectiveness. The findings revealed a strong correlation between the IC and the ROA. Surprisingly, there was no connection in either sector between the IC and the firms ROE. Likewise, Rahman \& Ahmed (2012) also explored correlations between Bangladeshi company's IC, performance and market value, selected from three separate industriespharmaceuticals, textiles, and banking. Their research was also unable to establish any exact association of IC with performance and market value of the companies.

Furthermore, while researching the effect of intellectual capital on India's pharmaceutical industry's financial results, Vishnu \& Gupta (2014) extended VAIC model of Pulic (1998) by introducing relational capital (RC) as a new variable. Here also, the results of the authors show a positive association of IC with the firm's performance, but no significant relation is produced by the new variable RC.

Despite the fact that many reports in the literature claim that financial performance metrics and VAIC have a positive relationship. However, the question of which VAIC components boost firm's efficiency is still being debated. According to some studies like of Goh, 2005 and Mondal \& Ghosh, 2012, the most positive and significant impact of HCE was found on the firms' performance, other researchers like Ting \& Lean, 2009 and Puntillo, 2009; Joshi et al., 2013, and Al-Musalli \& $\mathrm{Ku}$ Ismail, 2014, argue that most significant and positive impact on the firm's performance is of CEE. In sum, despite the number of researches on the IC and performance of firms in developed and least developed economies, the above-mentioned findings seem to be inconclusive. Also developing countries are in very initial stages of understanding and utilizing the concept of IC (Kamath, 2008).

\section{Political Uncertainty}

Diamonte, Liew, and Stevens (1996) showed larger impact of the changes in political risk on return of emerging market than of the developed market. Moreover, the positive association of political risk and capital flight was also confirmed by evidence presented by Lensink, Hermes and Murinde (2000). As it's very difficult to quantify political risk, however, mostly anecdotal evidence has been found of the political risk effect on stock return. Further, none of the theory that is accepted commonly is present that relates IC to the firm's performance; the issue of their relationship is mainly, thus, empirical. Political risk sign, paradox holds that greater political risk contributes to lower equity returns for all investment groups (Lehkonen \& Heimonen, 2015; 
Perotti \& Van Oijen, 2001). Positive sign of political risk was found by Perotti and van Oijen (2001) in their study which is indication that the countries which are politically stable yield higher than those of more volatile financial markets. Portfolios that experience political risk reduction in their environment often yield better returns compared to high-risk portfolios (Diamonte et al., 1996). The political uncertainty and rising potential of South Asian economies as an alternative source of global investment are both factors that make them a unique setting for empirical study of the political risk-intellectual capital connection.

\section{Data and Methodology}

A sample of 280 firms listed in KSE100 obtained from Thomson Reuters Data Stream included in this analysis. Data availability includes an unbalanced dataset of panel from 2010 to 2019, a decade-long stretch. Some other scholars have also chosen such an extended period, including Pal and Soriya (2012); Kamath (2008); and Chen et al. (2005) because a decade long period provides enough data to produce robust results for this kind of research. It is also helpful in understanding the trends in IC efficiency. Though, IC is crucial for all forms of enterprises, whether public or private, big or small. (Kolachi \& Shah, 2013), one benefit of choosing public listed companies is the availability of data for the listed companies. Another benefit is reliability, as the audited reports of firms improves result reliability (Chen, 2005). Kolachi and Shah (2013) argues that intellectual capital is applicable to large companies and small enterprises so this study used data from all manufacturers that have been listed publicly.

For calculating the political risk part, author used International Country Risk Guide (ICRG) information. Analysts at ICRGs create risk assessments in over 140 countries. Their overall risk scores for countries consist of economic, financial, and political components. As the author has tried to measure the significance of political risk in the productivity of intellectual capital, the political portion of ICRG is used as a proxy for political risk.

As mentioned above, the VAIC model founded by Pulic $(1998,2004)$, is used to evaluate the efficiency of a bank's intellectual capital. To make the VAIC model more accurate, Nimtrakoon and Chase (2015) revised it by adding new dimension, that is to say, relational capital. Relational capital in the form of customer capital measured by advertising and marketing expenses has already been empirically investigated by many authors (Chen, 2005; Vishnu \& Gupta, 2014; Nadeem et al., 2017). The author also used the spending on ads as replacements of relational resources, keeping other variables, like VA and efficacy estimates, consistent with the original VAIC model.

\section{Dependent Variables}

Mostly, studies have used Return on Assets (ROA) as the primary measure for profitability (Ting \& Lean, 2009; Joshi et al., 2013; Hsu \& Wang, 2012; Clarke et al., 2011; Yalama, 2013), therefore, this study also established ROA as the performance measure. To determine the ROA, total assets of the company are divided by the net profit or loss of the company for the current year.

\section{Independent Variables}

VAIC and its components have been considered as the independent variables, and following equation has been used to determine the VAIC (Nimtrakoon and Chase, 2015; Vishnu \& Gupta, 2014; Nadeem et al., 2017; Chen, 2005):

$\mathrm{VAIC}=\mathrm{HCE}+\mathrm{CEE}+\mathrm{SCE}+\mathrm{CCE}$

In equation (1), VAIC represents to the value added intellectual coefficient, HCE represents the human capital efficiency, CEE represents to the capital employed efficiency, SCE represents to 
the structural capital efficiency and CCE represents to the customer capital efficiency.

In addition, following is the equation used to calculate the total value added (VA) created by firms (Nimtrakoon and Chase, 2015; Vishnu \& Gupta, 2014; Nadeem et al., 2017):

$\mathrm{VA}=\mathrm{NPAT}+\mathrm{EC}+\mathrm{DP} \& \mathrm{AM}+\mathrm{I}+\mathrm{T}$

In equation (2) VA represents the total value added, NPAT is net profit after tax for the year, depreciation and amortization is represented as DP\&AM. EC represents to the employee cost, 'I' represent the interest cost and ' $\mathrm{T}$ ' represents the taxes.

Given are the equations used to calculate the components of VAIC

$\mathrm{CEE}=\mathrm{VA} / \mathrm{CE}$
$\mathrm{HCE}=\mathrm{VA} / \mathrm{HC}$
$\mathrm{SC}=\mathrm{VA}-\mathrm{HC}$
$\mathrm{SCE}=\mathrm{SC} / \mathrm{VA}$
$\mathrm{CCE}=\mathrm{CC} / \mathrm{VA}$

In equations (3) to (7), CE represent the capital invested by an organization, HC represents the salaries and wages of the firm and SC represents the difference between VA and HC.

\section{Moderating variable}

Furthermore, polrisk (political uncertainty) from the ICRG data is used as a moderating variable to show the moderating impact of political risk on firm's profitability.

\section{Control Variables}

The control variables of the regression models (Model I to IV) are firm size (by taking Natural Log of Total Assets) and leverage (the Ratio of Long Term Debt to Total Assets).

\section{Regression Models and Hypotheses}

Table 1 shows four models where models I \& II has been used to observe the relationship among a firm's VAIC, financial performance (ROA), and VAIC components without the influence of a moderating variable. However, Models III and IV has been used to observe the relationship among ROA, VAIC and the components of VAIC with the interaction effect of moderating variable. Model I-IV also comprised of the Control variables.

Table 1

\begin{tabular}{|c|c|}
\hline Model & Regression Equation \\
\hline I & $F P_{i t}=\beta_{0}+\beta_{1} V A I C+$ Control $+\varepsilon_{i t}$ \\
\hline II & $F P_{i t}=\beta_{0}+\beta_{1} C E E_{i t}+\beta_{2} H C E_{i t}+\beta_{3} S C E_{i t}+\beta_{4} C C E_{i t}+$ Control $+\varepsilon_{i t}$ \\
\hline III & $F P_{i t}=\beta_{0}+\beta_{1}$ VAIC $_{i t}+\beta_{2}$ Polrisk $_{i t}+\beta_{3}$ VAIC $i t *$ Polrisk $_{i t}+$ Control $+\varepsilon_{i t}$ \\
\hline IV & $\begin{array}{c}F P_{i t}=\beta_{0}+\beta_{1} C E E_{i t}+\beta_{2} H C E_{i t}+\beta_{3} S C E_{i t}+\beta_{4} C C E_{i t}+\beta_{6} \text { Polrisk }_{i t}+\beta_{7} C E E_{i t} * \text { Polrisk }_{i t} \\
+\beta_{8} H C E_{i t} * \text { Polrisk }_{i t}+\beta_{9} S C E_{i t} * \text { Polrisk }_{i t}+\beta_{10} C C E_{i t} * \text { Polrisk }_{i t} \\
+ \text { Control }^{+\varepsilon_{i t}}\end{array}$ \\
\hline
\end{tabular}

The following hypothesis were used to measures the relationships using the models in Table 1:

H1. VAIC and ROA has significantly positive relationship.

$\mathrm{H} 2$. CEE and ROA has significantly positive relationship.

H3. HCE and ROA has significantly positive relationship.

H4. SCE and ROA has significantly positive relationship.

H5. CCE and ROA has significantly positive relationship. 
H6. VAIC and ROA is significantly moderated by political risk.

H7. CEE and ROA is significantly moderated by political risk.

H8. HCE and ROA is significantly moderated by political risk.

H9. SCE and ROA is significantly moderated by political risk.

H10. CCE and ROA is significantly moderated by political risk.

\section{Empirical Results}

Results of Pearson Correlation analysis are presented in Table 2, among the independent variables. Highest correlation is observed between CEE and ROA ( $r=0.4018)$, while negative but insignificant relationship is observed between SCE and ROA. No strong correlation among the independent variables is observed suggesting weak or non-existent multicollinearity problem among the independent variables.

Table 2. Pearson Correlations Analysis

\begin{tabular}{|lrrrrrrrrr|}
\hline & ROA & VAIC & CEE & HCE & SCE & CCE & LEVERAGE & SIZE & POLRISK \\
ROA & 1 & & & & & & & \\
VAIC & 0.025278 & 1 & & & & & & & \\
CEE & -0.0171 & 0.009487 & 1 & & & & & & \\
HCE & -0.0256 & 0.673978 & -0.06138 & 1 & & & & \\
SCE & -0.06265 & -0.04392 & 0.124776 & -0.13284 & 1 & & & \\
CCE & 0.401835 & -0.02089 & -0.07032 & -0.04947 & -0.02258 & & 1 & & \\
LEVERAGE & 0.871998 & 0.042496 & -0.08346 & -0.02395 & -0.0496 & 0.347967 & & \\
SIZE & -0.80768 & -0.0295 & 0.03136 & 0.021632 & 0.021081 & -0.35159 & -0.75688 & 1 \\
POLRISK & 0.05264 & -0.05127 & -0.03383 & -0.05906 & 0.007097 & 0.03368 & 0.05746 & 0.009702 & 1 \\
\hline
\end{tabular}

The relationships between the financial performance and the intellectual capital performance related to Model (I, II, III, and IV) are shown in the Table 3.

Table 3 Regression results with dependent variable ROA 


\begin{tabular}{|c|c|c|c|c|}
\hline Model & (I) & (II) & (III) & (IV) \\
\hline VAIC & $\begin{array}{l}-0.0000240 \\
(0.0000228)\end{array}$ & & $\begin{array}{l}-0.0000220 \\
(0.0000226)\end{array}$ & \\
\hline Leverage & $\begin{array}{l}0.594^{4 * *} \\
(0.0151)\end{array}$ & $\begin{array}{l}0.572^{* 4 *} \\
(0.0160)\end{array}$ & $\begin{array}{l}0.598^{4 * *} \\
(0.0151)\end{array}$ & $\begin{array}{l}0.577^{+00} \\
(0.0159)\end{array}$ \\
\hline Size & $\begin{array}{l}-0.0715^{* *+} \\
(0.00352)\end{array}$ & $\begin{array}{l}-0.0717^{*+*} \\
(0.00376)\end{array}$ & $\begin{array}{l}-0.0709^{* 4 *} \\
(0.00351)\end{array}$ & $\begin{array}{l}-0.0710^{* 4 *} \\
(0.00373)\end{array}$ \\
\hline CEE & & $\begin{array}{l}0.255^{\circ * 4} \\
(0.0539)\end{array}$ & & $\begin{array}{c}0.709 \\
(1.226)\end{array}$ \\
\hline $\mathrm{SCE}$ & & $\begin{array}{l}-0.0263^{* *} \\
(0.00868)\end{array}$ & & $\begin{array}{l}-0.0666 \\
(0.187)\end{array}$ \\
\hline HCE & & $\begin{array}{c}0.0000662 \\
(0.0329)\end{array}$ & & $\begin{array}{l}-1.426^{*} \\
(0.715)\end{array}$ \\
\hline $\mathrm{CCE}$ & & $\begin{array}{l}2.77 \mathrm{e}-08^{4+4} \\
(4.02 \mathrm{e}-09)\end{array}$ & & $\begin{array}{c}0.000000540^{4 * 0} \\
(8.65 \mathrm{e}-08)\end{array}$ \\
\hline Pol-Risk & & & $\begin{array}{c}0.00755^{*} \\
(0.00337)\end{array}$ & $\begin{array}{l}-0.0241 \\
(0.0210)\end{array}$ \\
\hline Pol*VAIC & & & $\begin{array}{l}0.00460^{* 4+4} \\
(0.00100)\end{array}$ & \\
\hline $\mathrm{Pol}^{*} \mathrm{CEE}$ & & & & $\begin{array}{l}-0.00909 \\
(0.0251)\end{array}$ \\
\hline $\mathrm{Pol}^{*} \mathrm{SCE}$ & & & & $\begin{array}{l}0.000839 \\
(0.00390)\end{array}$ \\
\hline Pol ${ }^{*} \mathrm{HCE}$ & & & & $\begin{array}{l}0.0297^{*} \\
(0.0148)\end{array}$ \\
\hline $\mathrm{Pol}^{*} \mathrm{CCE}$ & & & & $\begin{array}{c}-1.05 \mathrm{e}-08^{* * *} \\
(1.76 \mathrm{e}-09)\end{array}$ \\
\hline _cons & $\begin{array}{l}1.342^{4+2 *} \\
(0.0612)\end{array}$ & $\begin{array}{l}1.342^{4 * 4 *} \\
(0.0810)\end{array}$ & $\begin{array}{l}0.913^{4 * *} \\
(0.169)\end{array}$ & $\begin{array}{l}2.473^{*} \\
(1.020)\end{array}$ \\
\hline $\begin{array}{l}N \\
R^{2}\end{array}$ & $\begin{array}{l}1749 \\
0.805\end{array}$ & $\begin{array}{l}1531 \\
0.818\end{array}$ & $\begin{array}{l}1749 \\
0.808\end{array}$ & $\begin{array}{l}1531 \\
0.824\end{array}$ \\
\hline
\end{tabular}

\section{Discussion}

It can be concluded from the regression results that the four models presented in the study have statistically significant relationship. Following can be concluded by the comparison of explanatory power:

In model I, no significant relationship of overall VAIC was found for firms in manufacturing sector of Pakistan. Similar findings were also observed by Joshi et al. (2013) in Australia. Further in some studies, the authors presented that the VAIC has no effect on ROA (Mehralian et al., 2012; Maditinos et al., 2011).

In model II, when conducted with individual component analysis, the OLS estimates of physical capital efficiency (CEE) and customer capital efficiency (CCE) found highly significant and positive at $1 \%$ level of significance. On the other hand, result related to human capital efficiency (HCE) and firm's performance found to be insignificant for Pakistan.

In model III, political index is found positive and significant at the significance level of $10 \%$ for firms in Pakistan. Similarly, interaction effect of political risk with overall intellectual capital efficiency (VAIC) also found positive and significant at the significance level of $1 \%$ for the firms in Pakistan. On the other hand, when political risk is used as moderating variable in Model IV, the individual effect of each component is found to be different as compare to model II for firms in Pakistan. Customer capital efficiency (CCE) found positive and significant at the significance level of $1 \%$ for firms. In addition, Human capital efficiency (HCE) also found to be significant but negative at $10 \%$ level of significance. However, CEE and SCE are found to be 
insignificant in this model. The R2 varies from $80 \%, 82 \%, 81 \%$ and $82 \%$ from model I to IV respectively.

The above results reveal that the most significant components of intellectual capital are CEE and CCE for manufacturing sector of Pakistan. It implies that firms in Pakistan rely heavily on physical capital and relational capital for creation of the value for their business. The results of significant and positive relationship between physical capital and financial performance of firms in Pakistan is consistent with finding of other researches on intellectual capital, (Nadeem et al., 2017; Vishnu \& Gupta, 2014; Joshi et al., 2013; Clarke et al., 2011; Chan, 2009; Young et al., 2009; Ting \& Lean, 2009; Firer \& Williams, 2003a). Human capital efficiency coefficient (HCE) found to have relatively lesser effect on value creation in the manufacturing sector of Pakistan, which consistently match with most of the other related studies on intellectual capital (Nadeem et al., 2017; Vishnu \& Gupta, 2014; Joshi et al., 2013; Clarke et al., 2011; Chan, 2009; Young et al., 2009; Ting \& Lean, 2009; Firer \& Williams, 2003a).

The interaction effect of political index with overall intellectual efficiency is also significant and positive for firms in Pakistan. The significance of the result found similar as of Diamonte, Liew, and Stevens (1996). In addition, when added political risk as moderator with individual components in Model IV, CCE is again found as positively significant. The interaction effect of HCE and CCE also found significant but negative. Diamonte et al. (1996), suggested that portfolios which have experienced reduced political risk often yield better returns than high-risk portfolios. Finally, the empirical evidence gathered for the control variables in all four models reveals that firm size has a substantial and positive impact on firm efficiency. In Pakistan, however, the leverage ratio has a statistically important but negative impact on the firm's results.

\section{Conclusion}

These findings suggest that the IC of Pakistani firms is driven by physical efficiency coefficient (CEE), and the customer capital Efficiency (CCE), primarily. While the structural capital efficiency (SCE) also significantly affects but its relationship is negative. Although, human capital efficiency coefficient (HCE) has relatively lesser effect value creation in the manufacturing sector of Pakistan, which are consistently match with most of the other related studies on intellectual (Firer \& Williams, 2003a; Chan, 2009; Ting \& Lean, 2009; Young et al., 2009; Clarke et al., 2011; Joshi et al., 2013; Vishnu \& Gupta, 2014; Nadeem et al., 2017).

This study has employed relatively a larger firms' sample for a period of 10 years to examine the IC efficiency. As this study has also investigated the moderating role of political risk between IC, its components and firm performance. Considering most of the studies in Pakistan on the relationship between IC and firms, this research is a step forward in the research on intellectual capital.

\section{Recommendation}

Highly significant and positive result of customer capital efficiency (CCE) and Physical capital efficiency (CEE) implies that good performer firms in Pakistan rely heavily on physical capital and relational capital for the creation of the value for their business. It also implies that firms in Pakistan also realize the importance of relational capital for gaining competitive advantage. Therefore, it is recommended for the manufacturing firms in Pakistan to focus on the efficient utilization of physical and relational capital to gain competitive advantage.

In addition, significant moderating role of political risk suggest that in the situation of higher political risk, firms in Pakistan can earn profit on the basis of human and relational capital.

\section{Limitations and Future Directions}

The quantitative model has been used in this study for measuring IC efficiency, and therefore the 
qualitative factors might found to be ignored. Since there are other methods to measure IC performance available (i.e. balanced scorecard, market-to-book ratio, and Tobin's Q ratio etc.) therefore future studies may apply other IC measuring methods and may cover others sectors or companies. In addition, this study has further expanded to a new direction for future research by applying political uncertainty factor on IC and company performance, especially in a highly political uncertain environment. So, this basic idea can be further extended to add or include other risk factors i.e., economic and financial risk etc, and this study can serve the purpose of future reference.

\section{References}

Alhassan, A. L., Asare, N., Adcroft, A., \& Murphy, P. (2016). Intellectual capital and bank productivity in emerging markets: evidence from Ghana. Management Decision.

Al-Musali, M. A. K., \& Ismail, K. N. I. K. (2014). Intellectual capital and its effect on financial performance of banks: Evidence from Saudi Arabia. Procedia-Social and Behavioral Sciences, 164, 201-207.

Aruppala, D., Wickramasinghe, V., \& Mahakalanda, I. (2015a). Intellectual capital and financial performance in Sri Lankan Banks. In 6th International Conference on Business \& Information (ICBI-2015) (pp. 37-49).

Aruppalal, D., Wickramasinghe, V., \& Mahakalanda, I. (2015b). Intellectual Capital and Financial Performance in Sri Lankan Banks.

Ayub, U., Kausar, A. R., \& Qadri, M. M. (2017). Linking Human Capital and Organisational Innovative Capabilities of Financial Institutions: Evidence from a Developing Country of South Asia. Journal of Information \& Knowledge Management, 16(04), 1750042. https://doi.org/10.1142/S0219649217500423

Bayraktaroglu, A. E., Calisir, F., \& Baskak, M. (2019). Intellectual capital and firm performance: An extended VAIC model. Journal of Intellectual Capital.

Berzkalne, I., \& Zelgalve, E. (2014). Intellectual capital and company value. Procedia e Social and Behavioral Sciences, 110, 887e896.

Bontis, N. (2001a). Assessing knowledge assets: A review of the models used to measure intellectual capital. International Journal of Management Reviews, 3(1), 41-60.

Bontis, N. (1998). Intellectual capital: An exploratory study that develops measures and models. Management Decision, 36(2), 63-76. https://doi.org/10.1108/00251749810204142

Brooking, A. (1996). Intellectual capital, core asset for the third millennium enterprise. London: International Thomson Business Press.

Canibao, L., Garcia-Ayuso, M., \& Sanchez, P. (2000). Accounting for intangibles: a literature review. Journal of Accounting Literature, 19, 102e130.

Cabrilo, S., \& Dahms, S. (2018). How strategic knowledge management drives intellectual capital to superior innovation and market performance. Journal of Knowledge Management.

Cabrita, M., \& Vaz, J. L. (2005). Intellectual capital and value creation: Evidence from the portuguese banking industry. Electronic Journal of Knowledge Management, 4(1), 11-20.

Cahill, D., \& Myers, P. J. (2000). Intellectual capital and accounting concepts: Unresolved issues in human resource accounting. Annual Conference of the British Accounting Association, Manchester, 11-13.

Chen, G. P. (2005). Intellectual capital performance of commercial banks in Malaysia. Journal of Intellectual Capital, 6(3), 385-396. https://doi.org/10.1108/14691930510611120

Chen, M.-C., Cheng, S.-J., \& Hwang, Y. (2005). An empirical investigation of the relationship between intellectual capital and firms' market value and financial performance. Journal of Intellectual Capital, 6(2), 159e176.

Cisneros, M. A. I., \& Hernandez-Perlines, F. (2018). Intellectual capital and Organization performance in the manufacturing sector of Mexico. Management Decision. 
Clarke, M., Seng, D., \& Whiting, R. H. (2011). Intellectual capital and firm performance in Australia. Journal of Intellectual Capital.

Diamonte, R. L., Liew, J. M., \& Stevens, R. L. (1996). Political risk in emerging and developed markets. Financial Analysts Journal, 52(3), 71-76.

Edvinsson, Leif, \& Malone, M. (1997). Realizing your company's true value by finding its hidden brain power. Intellectual Capital.

Firer, S., \& Williams, S. M. (2003). Intellectual capital and traditional measures of corporate performance. Journal of Intellectual Capital, 4(3), 348e360.

Foray, D. (2006). Optimizing the use of knowledge. MIT press.

Gan, K., \& Saleh, Z. (2008). Intellectual capital and corporate performance of technologyintensive companies: Malaysia evidence. AJBA, 1(1), 113-130.

Goh, P. C. (2005). Intellectual capital performance of commercial banks in Malaysia. Journal of Intellectual Capital, 6(3), 385e396.

Hejazi, R., Ghanbari, M., \& Alipour, M. (2016). Intellectual, human and structural capital effects on firm performance as measured by Tobin's Q. Knowledge and Process Management, 23(4), 259-273.

Hsu, L.-C., \& Wang, C.-H. (2012). Clarifying the effect of intellectual capital on performance: The mediating role of dynamic capability. British Journal of Management, 23(2), 179205.

Iqbal, J., \& Zaib, J. (2017). Corporate Governance, Intellectual Capital and Financial Performance of Banks listed in Pakistan Stock Exchange. Pakistan Administrative Review, 1(3),175-196.

Joshi, M., Cahill, D., Sidhu, J., \& Kansal, M. (2013). Intellectual capital and financial performance: an evaluation of the Australian financial sector. Journal of Intellectual Capital, 14(2), 264e285.

Kamal, Rahim, N. A., Husin, N., \& Ismail, I. (2012). Intellectual capital and firm performance of commercial banks in Malaysia. Asian Economic and Financial Review, 2(4), 577.

Kamath, G. B. (2008). Intellectual capital and corporate performance in Indian pharmaceutical industry. Journal of Intellectual Capital, 9(4), 684e704.

Kaplan, R. S., \& Norton, D. P. (1996). The balanced scorecard: Translating strategy into action. Boston: Harvard Business School Press.

Kayacan, M., \& Alkan, N. (2005). Türkiye'deki bes, eri sermayenin ekonomik degeri ve Avrupa Birligi u"lkeleri ile kars,1las,tırılması. Ankara: Ziraat Bankası A.S, (Yayınları).

Khalique, M., Bontis, N., Bin Shaari, J. A. N., \& Isa, A. H. M. (2015). Intellectual capital in small and medium enterprises in Pakistan. Journal of Intellectual Capital.

Khalique, M., Nassir Shaari, J. A., Isa, A. H. B. M., \& Ageel, A. (2011). Relationship of intellectual capital with the organizational performance of pharmaceutical companies in Pakistan. Australian Journal of Basic and Applied Sciences, 5(12), 1964-1969.

Khalique, M., Shaari, J., \& Isa, A. (2011). Relationship of intellectual capital with the organizational performance of commercial banks in Islamabad, Pakistan. International Journal of Current Research, 3(6).

Khan, F. A., Khan, R., \& Khan, M. A. (2012). Impact of intellectual capital on financial performance of banks in Pakistan: Corporate restructuring and its effect on employee morale and performance. International Journal of Business and Behavioral Sciences, 2(6), 22-30.

Kianto, A., Sáenz, J., \& Aramburu, N. (2017). Knowledge-based human resource management practices, intellectual capital and innovation. Journal of Business Research, 81, 11-20. https://doi.org/10.1016/j.jbusres.2017.07.018

Kolachi, N. A., \& Shah, H. A. (2013). BRICS countries and their strategic HRD agenda in 2020. International Journal of Management \& Information Systems (IJMIS), 17(2), 105-112.

Lehkonen, H., \& Heimonen, K. (2015). Democracy, political risks and stock market Performance. Journal of International Money and Finance, 59, 77-99. 
Lensink, R., Hermes, N., \& Murinde, V. (2000). Capital flight and political risk. Journal of International Money and Finance, 19(1), 73-92.

Leopold, T. A., Manktelow, A., \& Chan, Q. (2020). Human capital as an asset: an accounting framework to reset the value of talent in the new world of work. World Economic Forum, Geneva, Switzerland.

Luthy, D. H. (1998). Intellectual capital and its measurement. Proceedings of the Asian Pacific Interdisciplinary Research in Accounting Conference (APIRA), Osaka, Japan, 16-17.

Lu, W.-M., Wang, W.-K., \& Kweh, Q. L. (2014). Intellectual capital and performance in the Chinese life insurance industry. Omega, 42(1), 65-74.

Makki, M. M., Lodhi, S. A., \& Rahman, R. (2008). Intellectual capital performance of Pakistani listed corporate sector. International Journal of Business and Management, 3(10), 45-51.

Meles, A., Porzio, C., Sampagnaro, G., \& Verdoliva, V. (2016b). The impact of the intellectual capital efficiency on commercial banks performance: Evidence 179 from the US. Journal of Multinational Financial Management, 36, 64-74.

https://doi.org/10.1016/j.mulfin.2016.04.003.

Mondal, A., \& Ghosh, S. K. (2012). Intellectual capital and financial performance of Indian banks. Journal of Intellectual Capital, 13(4), 515e530.

Nadeem, M., Gan, C., \& Nguyen, C. (2017). Does intellectual capital efficiency improve firm performance in BRICS economies? A dynamic panel estimation. Measuring Business Excellence, 21(1), 65-85. https://doi.org/10.1108/MBE-12-2015-0055.

Nadeem, M., Gan, C., \& Nguyen, C. (2018). The importance of intellectual capital for firm performance: Evidence from Australia. Australian Accounting Review, 28(3), 334-344.

Nimtrakoon, S. (2015). The relationship between intellectual capital, firms' market value and financial performance. Journal of Intellectual Capital.

Oppong, G. K., \& Pattanayak, J. K. (2019). Does investing in intellectual capital improve productivity? Panel evidence from commercial banks in India. Borsa Istanbul Review, 19(3), 219-227. https://doi.org/10.1016/j.bir.2019.03.001.

Ozkan, N., Cakan, S., \& Kayacan, M. (2017). Intellectual capital and financial performance: A study of the Turkish Banking Sector. Borsa Istanbul Review, 17(3), 190-198. https://doi.org/10.1016/j.bir.2016.03.001.

Pal, K., \& Soriya, S. (2012). IC performance of indian pharmaceutical and textile industry. Journal of Intellectual Capital, 13(1), 120e137.

Perotti, E. C., \& Van Oijen, P. (2001). Privatization, political risk and stock market development in emerging economies. Journal of International Money and Finance, 20(1), 43-69.

Pulic, A. (1998). Measuring the performance of intellectual potential in knowledge economy. In Paper presented at the 2nd McMaster World Congress on Measuring and Managing Intellectual Capital by the Austrian Team for Intellectual Potential.

Pulic, A. (2004). Intellectual capital e does it create or destroy value? Measuring Business Excellence, 8(1), 62e68.

Puntillo, P. (2009). Intellectual capital and business performance. Evidence from Italian banking industry. Journal of Corporate Finance, 4(12), 97e115.

Rahman, S., \& Ahmed, J. U. (2012). Intellectual capital efficiency: Evidence from Bangladesh. Advances in Management and Applied Economics, 2(2), 109.

Rehman, H. U., \& Zahid, A. (2011). Intellectual capital performance and its impact on corporate performance: An empirical evidence from MODARABA sector of Pakistan. Australian Journal of Business and Management Research, 1(5), 8.

Roos, J., Edvinsson, L., \& Dragonetti, N. C. (1997). Intellectual capital: Navigating the new business landscape. Springer.

Shumaila, J., \& Afza, T. (2014a). Relationship between intellectual capital and financial performance of Pakistan non-financial firms and a comparative study of textile and chemical industry. International Interdisciplianry Research Journal, 3(1), 67-80. 
Steward, T. (1991). Intellectual capital: Brainpower. Fortune, (June 3), 44.

Steward, T. A. (1997). Intellectual capital: The new wealth of nations. New York: Doubleday Dell Publishing Group, Inc.

Sumedrea, S. (2013). Intellectual capital and firm performance: A dynamic relationship in crisis time. Procedia Economics and Finance, 6, 137-144.

$\mathrm{Su}, \mathrm{H}$. Y. (2014). Business ethics and the development of intellectual capital. Journal of Business Ethics, 119(1), 87-98.

Ting, I. W. K., \& Lean, H. H. (2009). Intellectual capital performance of financial institutions in Malaysia. Journal of Intellectual Capital, 10(4), 588e599.

Vishnu, S., \& Gupta, V. K. (2014). Intellectual capital and performance of pharmaceutical firms in India. Journal of Intellectual Capital.

Wambai, U. S. K., Madya, D., Derashid, C. B., \& Ibrahim, I. B. (2019). CBM2019. PROCEEDING OF 5TH, 189.

World Bank. (1998). World development report 1998/1999: Knowledge for development. The World Bank.

Yalama, A. (2013). The relationship between intellectual capital and banking performance in Turkey: evidence from panel data. International Journal of Learning and Intellectual Capital, 10(1), 71e87.

Young, C.-S., Su, H.-Y., Fang, S.-C., \& Fang, S.-R. (2009). Cross-country comparison of intellectual capital performance of commercial banks in Asian economies. The Service Industries Journal, 29(11), 1565-1579.

Zambon, S. (2004). Intangibles and Intellectual Capital: An Overview of the Reporting Issues and Some Measurement Models. 